\title{
19
}

\section{Going Regional: Local Childcare Provision and Parental Work-Care Choices in Germany}

\author{
Pia S. Schober
}

This chapter argues that taking into account different levels of regional and local institutional variations within a county may have great potential for generating new insights on the drivers of family policy reforms as well as on mechanisms how family policies affect families' choices and well-being. Cash or tax benefits and leave entitlements involving monetary transfers are frequently regulated at the federal level and not heavily dependent on implementation by municipalities and on local infrastructure. Yet, the effects of monetary transfers on families might still vary by regional economic circumstances. The provision of services for families, such as early childhood education and care (ECEC), however, frequently shows even greater regional variation depending on local politics and economic capacities. Drawing on the case of Germany and focusing on early childhood education and care services, this chapter describes the existing regional variations across federal states and counties. Germany is an interesting case due to its federal structure of education and welfare policies. Furthermore, it provides an illustrative example of large and persistent economic and cultural differences in work and care ideals between East and West Germany and also more nuanced cultural and economic differences across other regions.

The chapter first describes the institutional context of ECEC provision in Germany and the existing variation in regional provision and take-up of services. It then reviews different theoretical perspectives on potential drivers

P. S. Schober $(\bowtie)$

University of Tübingen, Tübingen, Germany

e-mail: pia.schober@uni-tuebingen.de 
of policy variations at the municipality and federal state level and connects these to existing empirical evidence. The second part of the chapter proposes a framework for investigating socially stratified parental work-care choices at subnational levels by connecting a macro-micro rational choice perspective with the capability approach and the accommodation model of childcare choices. After reviewing existing evidence on the effects of regional variations in childcare provision on social inequalities in take-up, maternal employment, and work-family balance and on some of the mechanisms, the chapter concludes by pointing to research gaps and new frontiers of regional family policy analysis. It outlines the current challenges and new demands for data collection and linkages necessary to realize the full potential of regional family policy analysis.

\section{Institutional Context of Early Childhood Education and Care in Germany}

\section{Legislative and Regulatory Structure}

Early childhood education and care (ECEC) services are understood to include all forms of state-subsidized and regulated forms of group care for children under school age, including mostly childcare centers and to a lesser extent childminders. In Germany, a childminder is a licensed caregiver who looks after up to five children in their own home or third-party rooms. In Germany, ECEC services are not located within the public education system but within the child and youth welfare sector. Political responsibility for ECEC provision is shared between the federal government, the regional governments, and the municipalities (for more details, see Oberhuemer, Schreyer, \& Neuman, 2010). Legislative responsibility for all education and care services for children from birth to school entry (usually at age six) is mostly located at the federal government level under the auspices of the Federal Ministry for Family Affairs, Senior citizens, Women, and Youth. Federal legislation then needs to be transformed into independent laws at the regional level of the states ("Bundesländer"). Furthermore, municipalities and states are responsible for organizing and financing ECEC provision. In Germany, a guiding policy principle is subsidiarity. This principle states that "the 'lower-level' actor or institution should be given preference over the 'higher-level' actor or institution, on the condition that they can fulfil their task" (Richter, 2009, p. 238). With respect to childcare provision, this can be roughly interpreted as family before state, welfare organizations 
before state, local communities before state, and member state before federal state (Richter, 2009). It is originally a concept of Catholic social doctrine and not a general principle of German constitutional law, but the German Bundestag decided in the Children and Youth Act 1990 to apply this principle as guidance for the organization of early childhood education and care (Richter, 2009). In the course of Germany's welfare state enlargement, the principle of subsidiarity was interpreted in favor of (often church-related) nonprofit associations and led to a situation where government was obliged to fund the services provided by these nonprofit associations, while at the same time guaranteeing their independence from state interference (Zimmer et al., 2005). This led to administrative structures and political dynamics of childcare provision, in which voluntary sector associations, many of them church-affiliated, play an important role, especially in West Germany (Bode, 2003). Direct public provision by municipalities is more prevalent in the East German states than in West Germany. For-profit providers play a very limited role. Between 2014 and 2018, only about three percent of ECEC centers were run by for-profit providers with little change over time (Bertelsmann Stiftung, 2017; Statistisches Bundesamt, 2018). Only in some large cities for-profit providers make up a larger share, such as 19\% of ECEC centers in Hamburg (Bertelsmann Stiftung, 2017).

The financing costs of ECEC centers are largely covered by municipalities (about 47\%) and by the state (about 31\%), while parents pay on average about 14\% (Spiess, 2008). Municipalities are free to design the parental fee structure to cover the running expenses of ECEC centers under consideration of several criteria stipulated under the Code of Social Law. As a result, fees need to be dependent on the number of children in the family and the daily care hours (Naßmacher \& Naßmacher, 2007; Tepe \& Goerres, 2013). In addition, municipalities usually design fees to be income-dependent with high-earning households paying more (Schröder, Spiess, \& Storck, 2015). Fees in Germany are below the OECD average (OECD, 2015). In 2012, they amounted on average to 144 Euros per month and family (Schröder et al., 2015). In the past, around nine percent of parents paid no fees at all (Fuchs-Rechlin, 2008). Some German federal states and municipalities have provided prioritized access to ECEC slots for single parents who receive welfare support (Spiess, Berger, \& Groh-Samberg, 2008).

\section{Historical Developments in East and West Germany}

Before 1990, the institutional setting in West Germany was characterized by low levels of publicly subsidized ECEC provision for children under the age 
of three and by long but low-paid parental leave entitlements. Together with the joint taxation for couples and a family health insurance, still existing, this has frequently been classified as supported familialism (Hook, 2015) and is considered to suppress employment of second earners and, thus, reinforce gender inequality. By contrast, in East Germany, in the former German Democratic Republic, shorter parental leave and extensive provision of formal care for very young children encouraged a faster return to the labor market of mothers (Rosenfeld, Trappe, \& Gornick, 2004). Since reunification, employment trends among mothers with young children have converged somewhat and part-time employment has become the most prevalent arrangement to combine employment and family care in both regions (Konietzka \& Kreyenfeld, 2010). Since 1996, all children from age three years have been entitled to a slot in a German ECEC center ('Kindertageseinrichtung') for at least four hours a day. From age three, over 93 and $95 \%$ of children attended daycare in West and East Germany, respectively, in 2017 (Statistische Ämter des Bundes und der Länder, 2018). Yet, significant East-West variations in daily hours spent in care remain with 39\% of children attending full-day care (over seven hours a day) in West Germany in contrast to $74 \%$ in East Germany (Statistische Ämter des Bundes und der Länder, 2018).

Recent policy developments have promoted a dramatic expansion of ECEC services for children under three years. Since 2005, a federal law ("Tagesbetreuungsausbaugesetz," Deutscher Bundestag, 2004) stipulated that at a minimum, children under the age of three be offered the chance to enroll in an ECEC center if a lone parent or both parents are employed or in education or want to take up employment, or if no other support program promoting the child's welfare is available. A second law in 2008 ("Kinderförderungsgesetz," Deutscher Bundestag, 2008b) outlined that from August 2013 all children aged one or older are entitled to an ECEC slot for four-five hours per weekday. At first, the ECEC expansion was subject to considerable controversy among the parties in government. Therefore, the introduction of the legal entitlement to a childcare place from age one starting in August 2013 was complemented by the introduction of a small flat-rate cash-forcare benefit for parents who do not use formal childcare until the third birthday of the child (Leitner, 2010). This legislation was very contested, as it was predicted to reduce maternal employment and ECEC use among lowincome families (Haan \& Wrohlich, 2011). It was then abolished again in 2015. The "Kinderförderungsgesetz" in 2008 (Deutscher Bundestag, 2008c) also stipulated that youth welfare office districts should aim at providing a need-oriented supply of full-day places in ECEC institutions for all children from the age of three. 
In parallel to the expansion of childcare services, in 2007 the German government reformed the parental leave policy to resemble the Nordic-style parental leave more closely (Leitner, 2010). The main aim was to counteract the low fertility rates and associated welfare state financing challenges by reducing the income loss of middle- and high-income new parents, by facilitating maternal labor market return as well as paternal involvement in child care (Spiess \& Wrohlich, 2008). The policy consists of an incomerelated reimbursement at $67 \%$ of net earnings (capped at 1800 Euros per month) or a minimum of 300 Euros for twelve months. The reform also includes an individual leave entitlement of two months, which is reserved for each parent to incentivize paternal leave take-up (Deutscher Bundestag, 2008a). However, the parental leave policy still continues to offer a low flatrate benefit for mothers who were not employed before the birth and the possibility to take leave for three years, even if part of it is now unpaid (Leitner, 2010). Overall, despite a dramatic shift in German family and childcare policy, on closer inspection, current policies include elements, which support both the traditional breadwinner and the dual-earner/carer model. In combination, Germany, therefore, has moved toward a model of optional familialism (Stahl \& Schober, 2018). As will be shown next, this provides a lot of room for regional variations in provision and social inequalities in take-up.

\section{Regional Variation in Childcare Take-up}

In Germany, the differences in the supply of ECEC slots for children under the age of three are particularly large between East and West Germany. However, even within these two regions, there are substantial variations across states, counties, and municipalities (Statistisches Bundesamt, 2011), depending on the financial situation of these regions and the political priority given to the provision of ECEC services. Some German states, such as Saxony, Thuringia, and Rhineland-Palatine, have entitled specific groups of children under three years of age earlier to a slot in a childcare center before the childcare entitlement at the federal level came into effect in 2013. As shown in Fig. 19.1, in 2017 coverage rates in ECEC for children under three years varied from about $27 \%$ in North Rhine-Westphalia, Bavaria, Bremen, and Baden-Wuerttemberg to about 56\% in Saxony, Saxony-Anhalt, and Brandenburg and Mecklenburg-West Pomerania. At the municipality level, variations are even larger with less than $20 \%$ of children attending ECEC in several Bavarian counties and only five cities in West Germany over $40 \%$ of children attended ECEC institutions. By contrast, the attendance rates across 

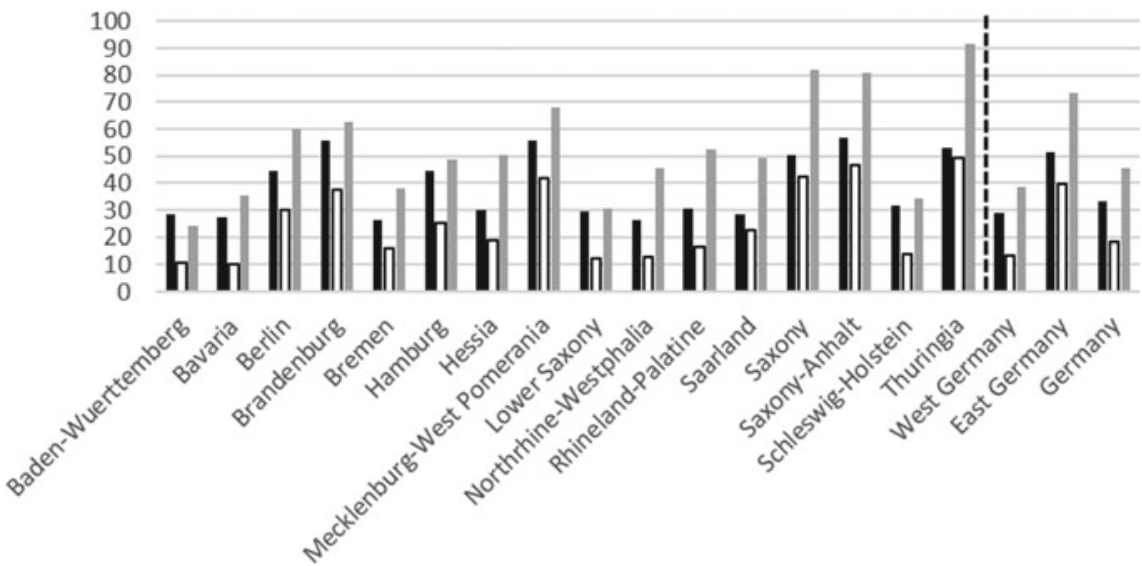

Fig. 19.1 ECEC attendance rates across Germany states and regions in 2017, in percent (Source Statistische Ämter des Bundes und der Länder [2018]. Kindertagesbetreuung Regional 2017. Wiesbaden: Statistisches Bundesamt)

East German cities and counties were mostly above 50\% (Statistische Ämter des Bundes und der Länder, 2018). The variation in hours of care is equally large. In 2017, the percentages of children under the age of three who were granted a full-day care slot, defined as more than seven hours per weekday, varied from about $10 \%$ in Bavaria and Baden-Wuerttemberg to close to $50 \%$ in Thuringia and Saxony-Anhalt. Among children aged three to six years, only $24 \%$ of children attended an ECEC institution for more than seven hours a day in Baden-Wuerttemberg compared to over $90 \%$ in Thuringia (Statistische Ämter des Bundes und der Länder, 2018).

\section{Regulation and Regional Variation of ECEC Quality}

Due to decentralization, German states and municipalities also vary greatly with respect to minimum quality standards for ECEC institutions. Minimum child-teacher ratios are regulated across all German states but the levels required for different ages vary between states (Viernickel et al., 2015). Minimum requirements for most other indicators of structural quality, such as group size, teacher qualifications, and further training, range from precise to very general or none at all. Minimum quality standards and actual conditions often fall short of evidence-based recommendations (Bock-Famulla, Strunz, \& Löhle, 2017; NAEYC, 2014). 

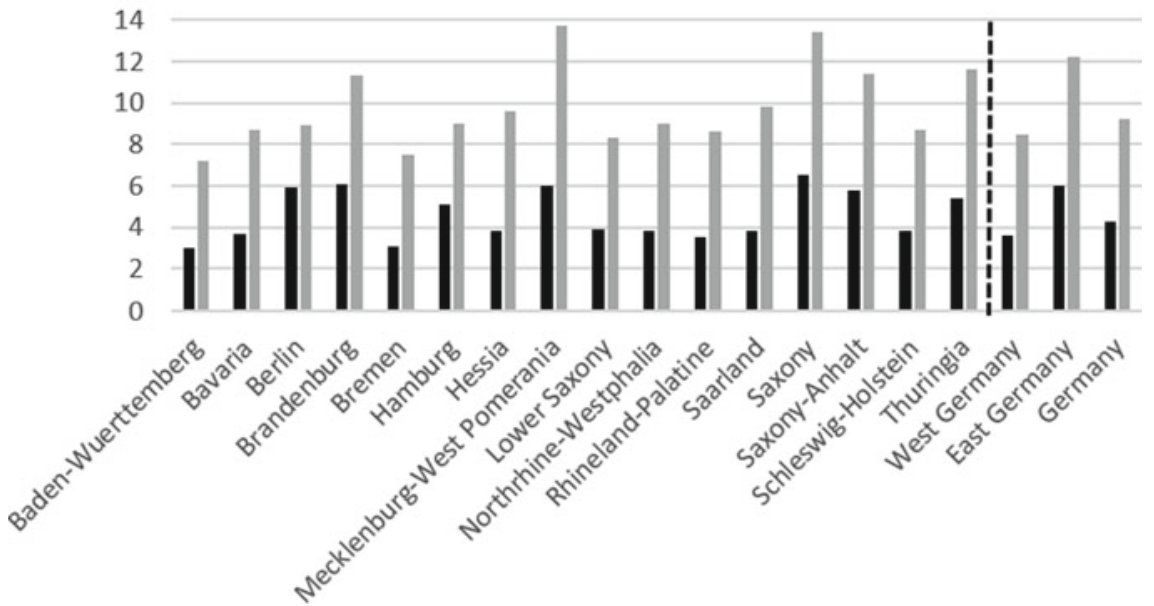

Fig. 19.2 Child-teacher ratios across German states in 2016 (Source Bock-Famulla, Strunz, \& Löhle, [2017]. Länderreport Frühkindliche Bildungssysteme 2017. Bertelsmann Stiftung)

As shown in Fig. 19.2, observed mean child-teacher ratios in ECEC institutions varied significantly across German states in 2016. Only BadenWuerttemberg and Bremen match the standards recommended by pedagogic experts of three children aged under three years per educator and 7.5 children per educator for older preschool children (Bock-Famulla et al., 2017; NAEYC, 2014). Actual child-teacher ratios in the majority of states, especially in East Germany, significantly exceed these recommendations. The stricter regulations in several West German states compared to most East German states have been found to be important drivers of the regional variations in the quality conditions of ECEC institutions (Stahl, 2017). Some German states provide additional funding to socially disadvantaged areas or ECEC centers serving disadvantaged children, but the specific regulations again vary across states (Hogrebe, 2014).

\section{Drivers of Regional Variation in Childcare Policy Provision}

Recently, a growing number of studies in political science have advocated for more attention to be paid to the subnational level of policy provision (Andronescu \& Carnes, 2015; Greer, Elliott, \& Oliver, 2015; Oliver \& Mätzke, 2014; Tepe \& Goerres, 2013). They have suggested that this may 
be particularly important for policies aimed at preventing or reducing new social risks, e.g., linked to the decline of the male breadwinner family model, or social investment policies, as these policies align less clearly with traditional party-political logics and are often subject to decentralization of some of the decision-making and most of the implementation.

As described above, one important driver of regional variation in childcare policy provision includes the extent to which regulatory powers, financing structures, and responsibilities for the implementation of childcare services are decentralized (Greer et al., 2015). While national governments have frequently engaged in large-scale campaigns of childcare expansion, the principles underlying decentralized implementation and the implementation structure for the deployment of funds affects the timing, pace, and nature of any expansion.

The political economy perspective has argued that partisan politics also play a crucial role in the design and implementation of childcare policy. Parties respond to social trends, such as the rise of female employment, but they also remain affine to their historical bases and ideological programs (Bonoli, 2005; Esping-Andersen, 1999; Huber \& Stephens, 2000; Williamson \& Carnes, 2013). In particular, leftist parties have long been associated with the expansion of social welfare spending and services, as well as with defamilialist service provision such as childcare. Such policies free parents, and especially women, from family care obligations and allow them to engage in the labor market. Conservative parties have tended to resist such expansions. Debates whether partisan politics are less influential at the municipal level compared to the nation-state level are still ongoing. Yet evidence for Germany generally points to some influence of political party representations on childcare expansions (Andronescu \& Carnes, 2015; Busemeyer \& Seitzl, 2018). By contrast, the "partisan convergence" approach has argued that parties with divergent ideological orientations have adopted overlapping policy goals regarding issues such as family policy due to the emergence of an increasingly de-aligned female vote (Morgan, 2013) and the presence of female political leaders supporting the expansion of childcare irrespective of their political party affiliation (Leitner, 2010).

In addition, several structural factors have been considered of importance for expanding public childcare institutions. First of all, demographic factors such as the prevalence of families with young children compared to older citizens and women's employment rates are likely to drive up the demand for childcare places for young children (Andronescu \& Carnes, 2015; Tepe $\&$ Goerres, 2013). Secondly, varying care ideals and acceptance of formal 
childcare for young children have been attributed to longer term ideological influences by religious institutions, such as the Catholic church in many European countries (Andronescu \& Carnes, 2015; Kremer, 2007). Thirdly, varying economic resources of states and municipalities are likely to provide different opportunities for additional spending on childcare. Next, I will consider each of these potential drivers more in detail for the case of German regions followed by a discussion of to-date evidence on their importance for subnational variation in childcare provision, quality, and fees.

\section{Evidence on the Importance of Partisan Politics, Female Representation, and Structural Variations Across German Regions}

Two studies have provided evidence for the relevance of partisan politics in the course of the German childcare expansion (Andronescu \& Carnes, 2015; Busemeyer \& Seitzl, 2018). The government participation of left-wing parties (SPD, Die Linke or the Greens) at the state level was positively and significantly associated with regional variations in the level of childcare availability for children under the age of three years with the expansion of such childcare slots since 2006 (Andronescu \& Carnes, 2015) as well as with changes in public spending on early childhood education between 1992 and 2010 (Busemeyer \& Seitzl, 2018). Tepe and Goerres (2013) also found that leftwing party majorities at the municipal level were associated with higher fees for groups of parents with medium and high incomes.

Qualitative studies have suggested that leading female politicians at the federal level played a key role in pushing through the childcare expansion in Germany (Leitner, 2010). At the municipal level, Tepe and Goerres (2013) found that fees were lower for high-income parents in city councils with a higher percentage of female representatives, irrespective of their political party affiliation. This suggests that they disproportionately favor affordable childcare for groups of women who are similar to themselves.

Economic and structural factors were frequently found to be important in driving regional variations in childcare availability, quality, and costs. These include economic resources of municipalities with wealthier municipalities spending more on ECEC services (Busemeyer \& Seitzl, 2018) and creating more childcare slots for under-threes (Andronescu \& Carnes, 2015). Structural ECEC quality conditions, such as child-teacher ratios, were also found to be more favorable in more affluent neighborhoods (Stahl, 2017). Furthermore, the higher the level of state spending on ECEC, the lower the fees for parents at the municipality level (Tepe \& Goerres, 2013). Also, Mätzke 
(2019) argued that East-West differences in the speed of the childcare expansion were influenced by the institutional legacy of long-standing differences in the childcare policies between the two regions. Due to more widespread childcare provision to start with and population decline, overcapacities for children over age three in East German regions were transformed into services for the younger age group. Population structure seems to matter with the percentage of children under the age of three being negatively associated with ECEC availability for this age group, whereas more widespread female employment shows a positive association (Andronescu \& Carnes, 2015). The population structure seems less important for the fee structure (Tepe \& Goerres, 2013). Whereas varying cultural legacies and childcare ideals seem crucial to understand the persistent differences in childcare provision between East and West Germany (Mätzke, 2019), greater prevalence of Catholicism among the population is not significantly associated with variations across states within East and West Germany, respectively (Andronescu \& Carnes, 2015).

\section{Conceptual Framework for Analyzing Effects of Regional ECEC Provision on Families}

This section will argue that taking into account local variations in childcare provisions is also promising for a better understanding of direct and indirect effects these might have on families and children. To develop a theoretical framework of how different aspects of childcare provision at the local level affect parents' opportunities and capabilities, we combine three theoretical perspectives: (1) a rational choice macro-micro perspective frequently applied in mechanism-based research and neighborhood studies (Coleman, 1990; Esser, 2009; Friedrichs \& Nonnenmacher, 2010), (2) the capability approach (Nussbaum, 2011; Sen, 1999), and (3) the accommodation model of childcare choices (Meyers \& Jordan, 2006).

All three approaches suggest that childcare policy and the characteristics of the local provision directly affect parents' opportunities and frame the choices they can make following childbirth. The first relevant perspective leads us back to the macro-micro model, originally developed by Coleman (1990) and extended by more recent proponents of wide versions of rational action theory (e.g., Esser, 2009; Hedström \& Ylikoski, 2010), especially in the context of analyzing neighborhood effects on micro-level actions (Friedrichs \& Nonnenmacher, 2010). One strength of this perspective is that it makes the distinction of direct and indirect effects and the need to specify chains of 
theoretical mechanisms very explicit. Friedrichs and Nonnenmacher (2010) distinguish between two mechanisms of direct effects of social contexts on individual outcomes: (i) local institutions that provide or hinder various activities, and (ii) collective socialization effects which provide normative settings for choice sets and the adoption of behaviors. The latter norm-setting processes have frequently been found to be nonlinear with stronger contagion effects above a certain threshold. With respect to regional and local childcare policies, variations in childcare services, such as availability of slots or opening hours are likely to directly affect parents' choices of employment hours. Indirect effects are equally conceivable, as reaching a certain threshold of childcare availability and take-up will change acceptability of this type of care arrangement and perceptions of entitlement to different combinations of employment and childcare. Indirect effects of childcare institutions may include effects on more intensified or reduced contact between specific groups of parents, e.g., by meeting during pick-up and drop-off. If characteristics of childcare institutions vary, e.g., in terms of quality and flexibility, in addition selection effects may occur with parents with similar preferences choosing the same institutions resulting in intensified social network and norm-setting effects.

The capability approach, originally developed by Sen (1999) and extended by Nussbaum (2011), offers the most comprehensive, yet also the least tangible, conceptualization of family outcomes and processes. In their application to childcare policy, Yerkes and Javornik (2018; see also Chapter 7 by Javornik and Yerkes in this Volume) refer to childcare policy as a resource for parents to arrange childcare in a way that allows for pluralist interpretations of what individuals have reason to value in life. Yerkes and Javornik (2018) suggest that five salient characteristics of childcare services comprise availability, accessibility, affordability, quality, and flexibility. According to their understanding, availability, accessibility, and affordability provide the foundation for childcare capabilities, whereas quality and flexibility only become more important once childcare is available, accessible, and affordable.

When considering parents' decision-making and resulting implications for outcomes, such as employment, work-family balance, and well-being, the capability approach assumes that even when individuals have equal access to means in terms of financial resources or childcare policy, they may not achieve the same outcomes or functionings (Sen, 1992). Key mechanisms here are variation in an individual's situated agency (Hobson, 2014, 2018) depending on conversion factors which reflect their individual resources and 
relational embeddedness in the community and social contexts. In combination, these may result in different capability sets representing different options and perceived alternatives from which individuals choose.

Similar to the capability approach, the accommodation model of childcare choices has been developed to complement or even substitute a previously dominant rational choice perspective with a rather narrow economic framing (Becker \& Tomes, 1986; Blau, Ferber, \& Winkler, 2002). The latter has been frequently criticized for assuming that (i) parents are perfectly informed about all childcare options, and (ii) parents have homogeneous and relatively fixed ex-ante preferences for childcare characteristics (Chaudry, Henly, \& Meyers, 2010; Meyers \& Jordan, 2006). The accommodation model seeks to combine a rational action perspective of parents with insights on varying information on the childcare system, and the role of social networks in processing information and making decisions. It suggests that parents adapt their childcare preferences based on context-specific care availability and easily accessible information. From a capability perspective, one might argue that the accommodation model of childcare choices focuses on specific conversion factors-knowledge and preferences and their social embeddedness - that shape parents' agency and may, for instance, result in substantial social disparities in childcare capabilities and family functionings.

The three perspectives can be fruitfully combined, as the capability approach leaves a lot of scope for specifications of more detailed processes of how individual resources and conversion factors impact the extent to which institutional provisions as resources actually result in individual capability sets and achieved functionings. The combination with a more mechanism-based perspective on causal chains might enhance our understanding of direct and indirect effects of local childcare policy institutions and help to shed light on some of the key conversion factors, such as how individuals come to perceive different choice sets and develop a sense of entitlement to policy support. Childcare policy evaluation studies have frequently sought to analyze the effects of different aspects of childcare provision on social inequalities in take-up of childcare and on gender inequalities in employment and workfamily balance. This chapter therefore outlines how a combined framework may contribute new insights on these relationships. Social disparities are likely arise in part due to variations in individual means or resources, including gender, education, income, and time variations. Conversion factors are likely to vary at the community level depending on the presence of a partner and other social networks and their resources as well as at the societal level in terms of cultural norms which tend to vary by gender and ethnicity (for a graphical illustration, see Fig. 19.3). 


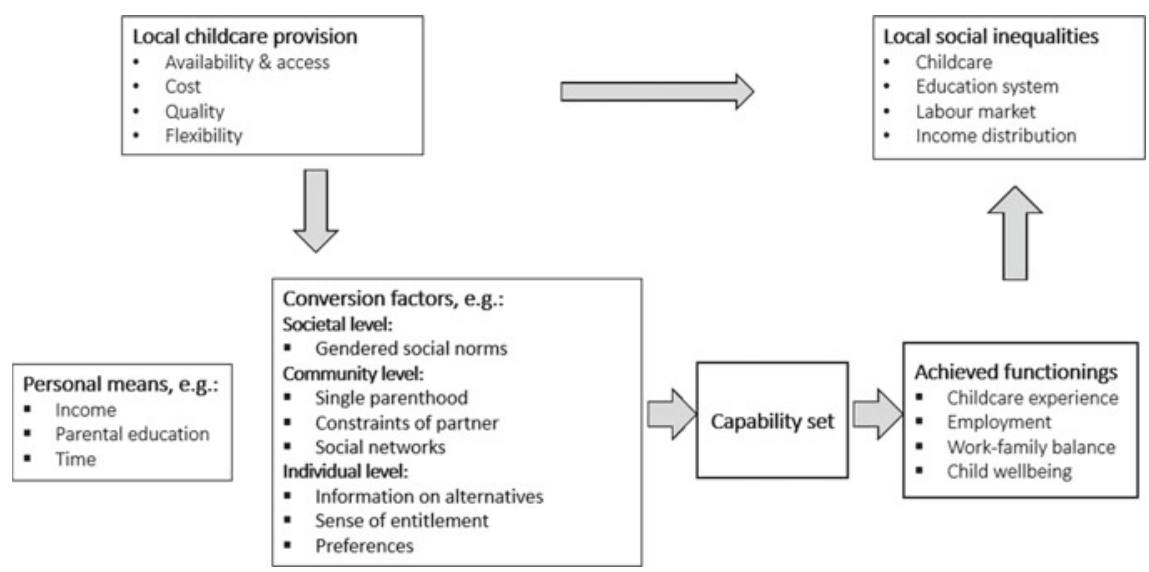

Fig. 19.3 Conceptual framework for analyzing effects of regional childcare provision (Source Adapted from Hobson [2018] and Javornik and Yerkes [Chapter 7 in this volume])

Depending on the national and local childcare institutions, personal and community resources will vary in their importance for shaping achieved functionings. Higher childcare costs, for instance, will increase income disparities, whereas prioritized access rights for single parents are likely to reduce the impact of partner resources. Cultural childcare norms and variations across gender and ethnic groups are reinforced by socially stratified networks, which also shape the accessible information. These moderate the process how national and local childcare provisions convert into perceived childcare alternatives and result in a varying sense of entitlement to childcare arrangements with valued characteristics. The resulting capability set is likely to show substantial variation which is then also reflected in different achieved functionings in terms of actual childcare experiences, parental employment, and work-family balance. These achieved functionings at the individual level in turn affect inequalities in childcare and education experiences as well as longer term labor market outcomes including income inequalities.

\section{Evidence on Effects of Local Childcare Provisions and Potential Mediators}

In Germany, parents can generally choose freely between ECEC centers, as there are no designated catchment areas. A recent analysis (Stahl, 2017) found that three-quarters of parents choose centers within 2.1 kilometers of their home (for similar analysis of parents' proximity to childcare institutions in the Netherlands, see Chapter 20 by Emery in this Volume). Given parents' 
strong preference for centers close to their home, families in densely populated areas likely enjoy much greater choice than families in rural areas. For instance, an analysis based on geocodes from Berlin suggests that, in the inner city, families often have 20 and more centers at close range (Franke, Pieper, Kürten, \& Schweikart, 2015). In the representative $K^{2} I D$ survey from 2013 to 2014 , however, $91 \%$ of parents reported that they had some choice between different centers (Stahl, Schober, \& Spiess, 2018). As described above, childcare resources in terms of availability and opening hours are more restrictive in the West compared to East Germany, whereas structural quality characteristics tend to be more advantageous in some West German regions. With respect to all these characteristics as well as costs, German counties and municipalities, however, show substantial variations.

Existing studies provide consistent evidence of pronounced, and even increasing, social inequalities by education and migration background in take-up of childcare institutions, especially for children under three years of age and with respect to full-day care also for older children (Jessen, Schmitz, Spiess, \& Waights, 2018; Schober \& Spiess, 2013; Schober \& Stahl, 2014; Stahl \& Schober, 2018). Interestingly, the increase in social disparities in childcare take-up and maternal employment unfolded in similar ways in East and West Germany. Drawing on data from the International Social Survey Program from 1994, 2002, and 2012, Schober \& Stahl, 2014 also found that the change toward less traditional gender ideologies was more pronounced among medium and highly educated respondents compared to the low educated both in East and West Germany. However, the drivers of increasing social disparities in childcare take-up and attitudes toward maternal employment are likely to differ between East and West Germany. In West Germany, the new incentives of shorter but income-related parental leave benefits in combination with wider availability of formal childcare corresponded better with labor market opportunities and work orientations of higher-educated mothers and enabled them to achieve their desired combination of employment with formal childcare. In East Germany, despite previously dominant cultural norms of full-time employment, the constantly lower job prospects may have kept low educated mothers from returning to the labor market faster and from using the increasingly available childcare resources from early on (Stahl \& Schober, 2018).

Notably, social disparities between education groups so far have not narrowed since the introduction of the legal entitlement to a childcare place (Jessen et al., 2018). Variation in financial means in terms of household income seems to be of lesser importance in the German context (Schober $\&$ Spiess, 2013), probably due to the income-dependent fee structure. Single 
mothers have been found to disproportionately increase their childcare takeup in the process of the recent expansion of childcare availability, possibly because they have been entitled to prioritized access across many municipalities (Stahl \& Schober, 2018). Recent studies also provide some evidence of modest differences in quality characteristics of ECEC institutions attended by children whose parents vary in their individual means of education and social normative conversion factors related to ethnic backgrounds (Becker \& Schober, 2017; Stahl et al., 2018). Again, household income and single motherhood was not systematically associated with lower quality of ECEC institutions as part of the achieved childcare functionings (Stahl et al., 2018).

By connecting regional data of the ECEC expansion for under-three-yearold children with individual-level survey data, Zoch and Hondralis (2017) found that mothers in regional counties with greater childcare availability returned earlier to the labor market after a second birth. They also found positive effects on the probability of mothers returning to part-time or fulltime employment as opposed to marginal employment. This might be partly explained by altered conversion factors in the form of increasing social acceptance of maternal employment and formal care for young children among mothers in West German regions where ECEC availability increased substantially from a relatively low level (Zoch \& Schober, 2018). To answer the question whether the greater availability of ECEC institutions contributed toward better reconciliation of employment and family care, two studies explored how the ECEC expansion for under-three-year-old children and the extension of childcare hours across counties was associated with changes in parents' subjective well-being. They found positive effects of the expansion of full-day childcare for all children up to school age on satisfaction with family life and with life overall for mothers in East Germany (Schober \& Stahl, 2016). In West Germany, the results only pointed to positive associations of full-day take-up of childcare resources for single mothers and full-time employed mothers. These results suggested that conversion factors seemed crucial, as mothers in East Germany may feel a greater sense of entitlement to using full-day childcare services also during spare time beyond their employment hours, which may be partly due to the greater availability as well as the greater cultural acceptance of formal childcare for young children. In West Germany, priority access was given to single mothers and to mothers who needed full-day care to cover their full-time work hours. As a result, probably these groups felt most entitled to using this type of care were able to convert the expanded childcare resources into greater subjective well-being. For the expansion of ECEC slots for under-threes, the 
results also pointed to improved functionings in terms of subjective wellbeing for single mothers (Schober \& Schmitt, 2017). Transitions to full-time employment were associated with reductions in subjective well-being irrespective of local availability of childcare resources among partnered mothers in West Germany but not in East Germany. These results suggested that the greater acceptance of maternal employment and formal childcare use in East compared to West Germany was a more important moderator of the relationship between maternal employment and satisfaction than short-term regional expansions of childcare resources. This points yet again to cultural conversion factors-possibly as a result of longer-term policy institutionsshaping perceived alternatives and the sense of entitlement. Fathers' subjective well-being seemed unaffected by variations in childcare resources, cultural conversion factors, and functionings in terms of different combinations of employment and care (Schober \& Schmitt, 2017).

\section{Evidence on Possible Mechanisms}

The observed social group differences in childcare capabilities might partly be owing to differences in conversion factors, such as preferences for specific childcare aspects (Klein, Biedinger, \& Kolb, 2016; Stahl et al., 2018) or in their information behaviors (Vandenbroeck, Visscher, \& Nuffel, 2008), which are likely to go hand in hand with a varying sense of entitlement to a high-quality childcare place.

Research from Germany as well as other countries suggests that parents' understanding of the childcare available, how to obtain a place, and subsidies, remains limited — especially among ethnically and linguistically more isolated groups (Becker, 2010; Burghardt \& Kluczniok, 2016; Vorsanger, 2005). Also, in terms of knowledge and perceptions of ECEC quality, studies have found significant discrepancies between parents and the care providers (Camehl, Schober, \& Spiess, 2018; Cryer \& Burchinal, 1997; Helburn \& Bergmann, 2002; Mocan, 2007) because it is difficult for parents to observe many qualitative features of childcare. Some studies from the US and several European countries found that parents with higher educational attainment rate the quality of their children's classrooms slightly lower and more accurately than less educated parents (Cryer, Tietze, \& Wessels, 2002; Mocan, 2007), whereas a recent German study found no systematic differences across education groups (Camehl et al., 2018). Less-educated as well as ethnic-minority and foreign-language families in Belgium (Vandenbroeck et al., 2008) were found to spend less time on the search and to register later 
than other groups of parents. In Germany, Turkish parents visited on average fewer centers prior to registration than German parents (Klein et al., 2016).

A few US studies found that higher parental education or financial resources correlated with stronger preferences for ECEC quality criteria and less importance attached to practical concerns apart from costs (Johansen, Leibowitz, \& Waite, 1996; Peyton, Jacobs, O’Brien, \& Roy, 2001), whereas others did not (Cryer et al., 2002; Kensinger Rose \& Elicker, 2008). In Belgium, ethnic minority parents attached less importance to the quality of the ECEC infrastructure as well as the opening hours of a center than Belgian parents (Vandenbroeck et al., 2008). In Germany, parents with college education were nearly ten percentage points more likely to report characteristics of pedagogic quality (e.g., child-teacher ratios, pedagogical concept) as opposed to practical considerations (e.g., proximity, opening hours) as the most important criterion than those with lower levels of education (Stahl et al., 2018). Parents with migration background were more likely and native-German parents were less likely to use the nearest ECEC center if it had a large proportion of children with migration background (Klein et al., 2016).

Given that social networks tend to be stratified by location, race/ethnicity, and other sociodemographic characteristics (Chaudry, 2004), these factors will shape the conversion factors, including recommendations parents receive, their awareness of different alternatives and subsequently their childcare preferences and sense of entitlement. To better understand the mechanisms of childcare capabilities, future studies need to go down to the regional and local levels to actually consider local provisions jointly with parents' personal means and conversion factors which drive their subsequent childcare experiences and family functionings. To-date, there is no systematic evidence as to how key aspects of local childcare provision, such as availability and quality, might moderate the importance of different conversion factors for explaining social and gender inequalities.

\section{Discussion}

The first part of this chapter has described the institutional context of ECEC provision and the pronounced regional variations. It then reviewed different theoretical perspectives on potential drivers of childcare policy variations at the municipality and federal state level. In line with the international literature (Greer et al., 2015), one important driver of substantial regional variation in German childcare policy provision is the decentralization of 
regulatory powers, financing structures, and responsibilities for the implementation of childcare services. Whereas in other countries, debates whether partisan politics are less influential at the municipal level compared to the nation-state level are still ongoing, evidence for Germany generally points to some influence of political party representations and female political leaders at federal state and municipality level during the recent childcare expansion (Andronescu \& Carnes, 2015; Busemeyer \& Seitzl, 2018; Tepe \& Goerres, 2013). In addition to varying economic resources of states and municipalities, the supply of childcare services is also affected by the demand of voter groups in terms of the share of families with children and female employment rates. Furthermore, differing cultural care ideals seem crucial to understand the persistent East-West differences (Mätzke, 2019).

The second part of the chapter proposed the cornerstones of a conceptual framework for investigating socially stratified parental work-care functionings at subnational levels. It has connected a macro-micro rational choice perspective of neighborhood effects with the capability approach and the accommodation model of childcare choices. It outlined how the study of social inequalities in childcare experiences and gender inequalities in employment and work-family balance might benefit from combining the conceptualization of the capability approach with a more mechanism-based perspective on direct as well as indirect effects of local childcare policy institutions. This would help to shed light on specific conversion factors, such as how individuals come to perceive different choice sets and develop a sense of entitlement to policy support. In particular, the framework has aimed to give specific examples how variations in individual means, such as education and income, and conversion factors, for instance, in terms of social networks, are likely to lead to variations in perceived and preferred alternatives and a substantially different sense of entitlements and subsequent access to high-quality childcare. Depending on the local childcare institutions, these resources and conversion factors will vary in their importance in shaping achieved functionings. Furthermore, cultural childcare norms, which are frequently socially stratified e.g., with respect to gender and ethnicity, moderate these processes. The resulting capability set is likely to show substantial variation which is then also reflected in different achieved functionings in terms of actual childcare experiences, maternal employment, and work-family balance. The review of existing empirical studies on the effects of regional and local childcare provision in Germany pointed to substantial social inequalities in quantity and quality of childcare take-up (Stahl \& Schober, 2018; Stahl et al., 2018) and to heterogeneous effects on maternal employment (Zoch, 2018; Zoch \& Hondralis, 2017) and work-family balance (Schober \& Schmitt, 
2017; Schober \& Stahl, 2016). It provides examples of the moderating role of work-care culture in explaining not only persistent differences in childcare take-up and maternal employment but also differences in the effects of the recent childcare expansion between the East and West Germany (Schober \& Schmitt, 2017; Schober \& Stahl, 2016). It also presented existing evidence of some key conversion processes through socially stratified information on available alternatives, sense of entitlements, and preferences for varying childcare arrangements (Mocan, 2007; Stahl et al., 2018; Vandenbroeck et al., 2008).

Yet, it also became obvious that we are still missing empirical evidence on a number of pieces in the puzzle. In particular, the indirect effects of local childcare institutions through forming and reinforcing social networks and norm-setting processes would hold great promise for future research on social stratification of childcare experiences as well as parental employment and work-family balance. Another open question concerns the most appropriate level of analysis. Depending on the outcomes of interest and the specific political and legislative context, a close link to boundaries marked by political institutions or even smaller local neighborhoods aligning more closely with social network might be favorable. To dive deeper into these issues, statistical offices in Germany as well as other countries would need to collect and provide easier access to detailed data at different regional levels and allow linking these with large-scale survey data on social networks. Another interesting extension would be to extend a few existing studies (Neimanns, 2017; Zoch \& Schober, 2018) on policy feedback processes by examining how the expansion of childcare shapes voters' work-care attitudes and ideals over the short- and long-term and how this in turn affects positions of political parties and subsequent reforms. Subnational analyses of countries with decentralized structures, such as Germany, are particularly promising to investigate how substantial regional and social inequalities and shorter term variations therein influence future policy development within similar long-term cultural and institutional contexts.

The theoretical frameworks applied for exploring key drivers of childcare provision and consequences for families are equally applicable to other social policies with decentralized responsibilities of legislation and implementation, which frequently is the case for child welfare and protection policies, education policies, or labor market activation programs. Accordingly, some of the findings regarding important conversion processes which shape social inequalities and family functionings may be transferable to these other policy domains. On the whole, the aim of this chapter was to show that subnational 
analyses exploiting regional variations have great potential. Given data availability at local levels, subnational analyses are likely to be advantageous over cross-national comparisons or historical single-country studies, for instance, by allowing a closer identification of direct and indirect effects of local policies and institutions and for analyzing the determinants and consequences of reforms separately from longer term cultural and institutional context factors.

\section{References}

Andronescu, C. G., \& Carnes, M. E. (2015). Value coalitions and policy change: The impact of gendered patterns of work, religion and partisanship on childcare policy across German states. Journal of European Social Policy, 25(2), 159-174.

Becker, B. (2010). Ethnische Unterschiede bei der Kindergartenselektion: Die Wahl von unterschiedlich stark segregierten Kindergärten in deutschen und türkischen Familien. In D. R. B. Becker (Ed.), Vom Kindergarten bis zur Hochschule. Die Generierung von ethnischen und sozialen Disparitäten in der Bildungsbiographie (pp. 17-47). Wiesbaden: VS Verlag für Sozialwissenschaften.

Becker, B., \& Schober, P. S. (2017). Not just any child care center? Social and ethnic disparities in the choice of early education institutions with a beneficial learning environment. Early Education \& Development, Published online: 19 May, 28, 1011-1034.

Becker, G. S., \& Tomes, N. (1986). Human capital and the rise and fall of families. Journal of Labor Economics, 4(3), 1-39.

Bertelsmann Stiftung. (2017). KiTas nach Träger. Ländermonitor Frühkindliche Bildungssysteme. Retrieved from https://www.laendermonitor.de/de/vergleichbundeslaender-daten/personal-und-einrichtungen/traeger/kitas-nach-traeger/?tx_ itaohyperion_pluginview $\% 5$ Baction $\% 5 \mathrm{D}=$ chart\&tx_itaohyperion_pluginview\% 5Bcontroller\%5D=PluginView\&cHash=ed117cbe6f47e7f97710f316c3b6e300.

Blau, F. D., Ferber, M. A., \& Winkler, A. E. (2002). The economics of women, men, and work. Upper Saddle River, NJ: Prentice-Hall.

Bock-Famulla, K., Strunz, E., \& Löhle, A. (2017). Länderreport Frühkindliche Bildungssysteme 2017. from Bertelsmann Stiftung. https://www.bertelsmannstiftung.de/fileadmin/files/BSt/Publikationen/imported/leseprobe/LP_978-386793-786-3_1.pdf.

Bode, I. (2003). The organizational evolution of the childcare regime in Germany: Issues and dynamics of a public-private partnership. Annals of Public and Cooperative Economics, 74(4), 631-657.

Bonoli, G. (2005). The politics of the new social policies: Providing coverage against new social risks in mature welfare states. Policy and Politics, 33(3), 431-450.

Burghardt, L., \& Kluczniok, K. (2016). Erwartungen von Eltern zu Nutzen und Kosten eines Krippenbesuchs - Eine Analyse zu Zusammenhängen mit kindbezogenen und familialen Strukturmerkmalen. Diskurs Kindheits- Und Jugendforschung, 11(3), 339-354. 
Busemeyer, M. R., \& Seitzl, L. (2018). The partisan politics of early childhood education in the German Länder. Journal of Public Policy, 38(2), 243-274.

Camehl, G. F., Schober, P. S., \& Spiess, C. K. (2018). Information asymmetries between parents and educators in German childcare institutions. Education Economics, Published online: 26 Apr, 26, 624-646.

Chaudry, A. (2004). Putting children first: How low-wage working mothers manage child care. New York: Russell Sage Foundation.

Chaudry, A., Henly, J., \& Meyers, M. (2010). Conceptual frameworks for child care decision-making (Acf-Opre White Paper). Washington, DC: U.S. Department of Health and Human Services.

Coleman, J. (1990). Foundations of social theory. Cambridge, MA: Belknap Press.

Cryer, D., \& Burchinal, M. (1997). Parents as child care consumers. Early Childhood Research Quarterly, 12, 35-58.

Cryer, D., Tietze, W., \& Wessels, H. (2002). Parents' perceptions of their children's child care: A cross-national comparison. Early Childhood Research Quarterly, 17, 259-277.

Deutscher Bundestag. (2004). Entwurf eines Gesetzes zum qualitätsorientierten und bedarfsgerechten Ausbau der Tagesbetreuung und zur Weiterentwicklung der Kinder- und Jugendhilfe (Tagesbetreuungsausbaugesetz - TAG). BundestagsDrucksache Nr. 15/3676.

Deutscher Bundestag. (2008a). Bericht über die Auswirkungen des Bundeselterngeld- und Elternzeitgesetzes sowie über die gegebenenfalls notwendige Weiterentwicklung. Bundestags-Drucksache, Nr. 16/10770.

Deutscher Bundestag. (2008b). Entwurf Eines Gesetzes Zur Förderung Von Kindern Unter Drei Jahren in Tageseinrichtungen Und in Der Kindertagespflege (Kinderförderungsgesetz - Kifög). Bundestags-Drucksache Nr. 16/9299.

Deutscher Bundestag. (2008c). Entwurf eines Gesetzes zur Förderung von Kindern unter drei Jahren in Tageseinrichtungen und in der Kindertagespflege (Kinderförderungsgesetz - KiföG). Bundestags-Drucksache, Nr. 16/9299.

Esping-Andersen, G. (1999). The social foundations of postindustrial economies. Oxford: Oxford University Press.

Esser, H. (2009). Rationality and commitment: The model of frame selection and the explanation of normative action. In M. Cherkaoui \& P. Hamilton (Eds.), Raymond Boudon: A life in sociology (pp. 207-230). Oxford: The Bardwell Press.

Franke, C., Pieper, J., Kürten, C., \& Schweikart, J. (2015). GIS-gestützte kleinräumige Kita-Versorgungsanalyse am Beispiel von Berlin-Pankow. In J. Strobl, T. Blaschke, \& G. Griesebner (Eds.), Angewandte Geoinformatik 2015. Beiträge zum 27. AGIT-Symposium Salzburg. Heidelberg: Wichmann.

Friedrichs, J., \& Nonnenmacher, A. (2010). Welche Mechanismen erklären Kontexteffekte? In T. Beckers, K. Birkelbach, J. Hagenah, \& U. Rosar (Eds.), Komparative empirische Sozialforschung (pp. 469-498). Wiesbaden: VS Verlag/ Springer.

Fuchs-Rechlin, K. (2008). Soziale Hintergründe der Inanspruchnahme von Kindertagesbetreuung und finanzieller Aufwand der Eltern - Auswertungen des Sozio-ökonomischen Panels. Retrieved from Munich. 
Greer, S., Elliott, H., \& Oliver, R. (2015). Differences that matter: Overcoming methodological nationalism in comparative social policy research. Journal of Comparative Policy Analysis: Research and Practice, 17(4), 408-429. https://doi. org/10.1080/13876988.2015.1060713.

Haan, P., \& Wrohlich, K. (2011). Can child care policy encourage employment and fertility? Evidence from a structural model. Labour Economics, 18(4), 498-512.

Hedström, P., \& Ylikoski, P. (2010). Causal mechanisms in the social sciences. Annual Review of Sociology, 36, 49-67.

Helburn, S., \& Bergmann, B. R. (2002). America's childcare problem: The way out. New York: Palgrave Press.

Hobson, B. (2014). Worklife balance: The agency and capabilities gap. Oxford: Oxford University Press.

Hobson, B. (2018). Gendered dimensions and capabilities: Opportunities, dilemmas and challenges. Critical Sociology, 44, 883-898.

Hogrebe, N. (2014). Bedarfsorientierte Finanzierung von Kindertageseinrichtungen. In N. Hogrebe (Ed.), Bildungsfinanzierung und Bildungsgerechtigkeit: Der Sozialraum als Indikator für eine Bedarfsgerechte Finanzierung von Kindertageseinrichtungen? (pp. 165-188). Wiesbaden: Springer VS.

Hook, J. L. (2015). Incorporating 'Class' into work-family arrangements: Insights from and for three worlds. Journal of European Social Policy, 25(1),14-31.

Huber, E., \& Stephens, J. D. (2000). Partisan governance, women's employment and the social democratic service state. American Sociological Review, 65(3), $323-$ 342.

Johansen, A., Leibowitz, A., \& Waite, L. J. (1996). The importance of child-care characteristics to choice of care. Journal of Marriage and the Family, 58, 759-772.

Jessen, J., Schmitz, S., Spiess, C. K., \& Waights, S. (2018). Kita-Besuch hängt trotz ausgeweitetem Rechtsanspruch noch immer vom Familienhintergrund ab. DIW Wochenbericht 2018, 85(38), 825-835.

Kensinger Rose, K., \& Elicker, J. (2008). Parental decision making about child care. Journal of Family Issues, 29, 1161-1184.

Klein, O., Biedinger, N., \& Kolb, J.-P. (2016). Ethnische Unterschiede bei der Wabl des Kindergartens: Wer wählt den nächstgelegenen Kindergarten? Paper presented at 2016 Meeting of the Society of Empirical Educational Research.

Konietzka, D., \& Kreyenfeld, M. (2010). The growing educational divide in mothers' employment: An investigation based on the German micro-censuses 1976-2004. Work, Employment \& Society, 24(2), 260-278.

Kremer, M. (2007). How welfare states care: Culture, gender and parenting in Europe. Amsterdam: Amsterdam University Press.

Leitner, S. (2010). Germany outpaces Austria in childcare policy: The historical contingencies of 'conservative' childcare policy. Journal of European Social Policy, 20(5), 456-467. https://doi.org/10.1177/0958928710380482.

Mätzke, M. (2019). Comparative perspectives on childcare expansion in Germany: Explaining the persistent East-West divide. Journal of Comparative Policy Analysis: Research and Practice, 21(1), 47-64. 
Meyers, M. K., \& Jordan, L. P. (2006). Choice and accommodation in parental child care decisions. Community Development, 37(2), 53-70.

Mocan, N. (2007). Can consumers detect lemons? An empirical analysis of information asymmetry in the market for child care. Journal of Population Economics, 20, 743-780.

Morgan, K. J. (2013). Path shifting of the welfare state: Electoral competition and the expansion of work-family policies in Western Europe. World Politics, 65(1), 73-115.

NAEYC. (2014). NAEYC early childhood program standards and accreditation criteria \& guidance for assessment. Retrieved January 6, 2015, from http://www.naeyc. org/academy/primary/viewstandards.

Naßmacher, H., \& Naßmacher, K.-H. (2007). Kommunalpolitik in Deutschland: VS Verlag.

Neimanns, E. (2017). Public opinion and social investment : How politicalinstitutional context shapes support and opposition towards expanding childcare. Ph.D. thesis, University of Konstanz, Konstanz.

Nussbaum, M. C. (2011). Creating capabilities: The human development approach. Boston, MA: Belknap Press of Harvard University Press.

Oberhuemer, P., Schreyer, I., \& Neuman, M. J. (2010). Professionals in early childhood education and care systems. Opladen: Barbara Budrich.

Oliver, R. J., \& Mätzke, M. (2014). Childcare expansion in conservative welfare states: Policy legacies and the politics of decentralized implementation in Germany and Italy. Social Politics: International Studies in Gender, State \& Society, 21(2), 167-193.

Organisation for Economic Co-operation and Development. (2015). Structural policy indicators. In Economic policy reforms 2015-Going for growth. Paris: OECD Publishing. https://doi.org/10.1787/growth-2015-51-en.

Peyton, V., Jacobs, A., O’Brien, M., \& Roy, C. (2001). Reasons for choosing child care: Associations with family factors, quality, and satisfaction. Early Childhood Research Quarterly, 16, 191-208.

Richter, I. (2009). Basic legal principles of public responsibility for children. In K. Scheiwe \& H. Willekens (Eds.), Childcare and preschool development in Europe: Institutional perspectives (pp. 234-246). Basingstoke: Palgrave Macmillan.

Rosenfeld, R. A., Trappe, H., \& Gornick, J. C. (2004). Gender and work in Germany: Before and after reunification. Annual Review of Sociology, 30, 103-124.

Schober, P. S., \& Schmitt, C. (2017). Day-care availability, maternal employment and satisfaction of parents: Evidence from cultural and policy variations in Germany. Journal of European Social Policy, published online February, 27, 433-446.

Schober, P. S., \& Spiess, C. K. (2013). Early childhood education activities and care arrangements of disadvantaged children in Germany. Child Indicators Research, $6(4), 709-735$. 
Schober, P. S., \& Stahl, J. F. (2014). Childcare trends in Germany-increasing socioeconomic disparities in East and West. DIW Economic Bulletin, 4(11), 51-58.

Schober, P. S., \& Stahl, J. F. (2016). Availability of full-day early education and care and subjective well-being of parents: Interdependencies with culture and resources. European Sociological Review, 32(5), 593-606.

Schröder, C., Spiess, C. K., \& Storck, J. (2015). Private spending on children's education: Low-income families pay relatively more. DIW Economic Bulletin, 8, 113-123. Retrieved from http://hdl.handle.net/10419/107604.

Sen, A. (1992). Inequality reexamined. Cambridge, MA: Harvard University Press.

Sen, A. (1999). Commodities and capabilities. Oxford: Oxford University Press.

Spiess, C. K. (2008). Early childhood education and care in Germany: The status quo and reform proposals. Zeitschrift für Betriebswirtschaftslehre, 67, 1-20.

Spiess, C. K., \& Wrohlich, K. (2008). The parental leave benefit reform in Germany: Costs and labour market outcomes of moving towards the Nordic model. Population Policy and Research Review, 27(5), 575-591.

Spiess, C. K., Berger, E. M., \& Groh-Samberg, O. (2008). Overcoming disparities and expanding access to early childhood services in Germany: Policy considerations and funding options (UNICEF Innocenti Research Centre Working Paper IWP2008-03).

Stahl, J. F. (2017). Socio-economic and regional inequalities in early care and education: Consequences for mothers' work-family life and children's educational opportunities. Unpublished doctoral dissertation, University of Tuebingen.

Stahl, J. F., \& Schober, P. S. (2018). Convergence or divergence? Educational discrepancies in work-care arrangements of mothers with young children in Germany. Work, Employment \& Society, 32(4), 629-649.

Stahl, J. F., Schober, P. S., \& Spiess, C. K. (2018). Parental socio-economic status and childcare quality: Early inequalities in educational opportunity? Early Childhood Research Quarterly, 44, 304-317.

Statistische Ämter des Bundes und der Länder. (2018). Kindertagesbetreuung Regional 2017. Wiesbaden: Statistisches Bundesamt.

Statistisches Bundesamt (Ed.). (2011). Kindertagesbetreuung regional 2010. Ein Vergleich aller 412 Kreise in Deutschland. Wiesbaden.

Statistisches Bundesamt. (2018). Statistiken der Kinder- und Jugendhilfe. Retrieved from https://www.destatis.de/DE/Themen/Gesellschaft-Umwelt/Soziales/Kinder tagesbetreuung/Publikationen/Downloads-Kindertagesbetreuung/tageseinrichtun gen-kindertagespflege-5225402187004.pdf?_blob=publicationFile\&v=6.

Tepe, M., \& Goerres, A. (2013). Für die Kleinen ist uns nichts zu teuer? Kindergartengebühren und ihre Determinanten in Deutschlands 95 bevölkerungsreichsten Städten zwischen 2007 und 2010. Der Moderne Staat: Dms (Zeitschrift Für Public Policy, Recht Und Management), 6(1), 169-190.

Vandenbroeck, M., Visscher, S. D., \& Nuffel, K. V. (2008). Mothers' search for infant child care: The dynamic relationship between availability and desirability in a Continental European welfare state. Early Childhood Research Quarterly, 23(2), 245-258. 
Viernickel, S., Fuchs-Rechlin, K., Bensel, J., Strehmel, P., Preissing, C., \& HaugSchnabel, G. (2015). Qualität für alle: Wissenschaftlich begründete Standards für die Kindertagesbetreuung. Herder Verlag GmbH.

Vorsanger, S. (2005). Parents' perspectives on child care subsidies. Dissertation, Columbia University School of Social Work.

Williamson, S., \& Carnes, M. (2013). Partisanship, christianity and women in the legislature: Determinants of parental leave policy in the U.S. states. Social Science Quarterly, 94(4), 1084-1101.

Yerkes, M. A., \& Javornik, J. (2018). Creating capabilities: Childcare policies in comparative perspective. Journal of European Social Policy, Published online November 28, 29, 529-544.

Zimmer, A., Appel, A., Dittrich, C., Lange, C., Sittermann, B., Stallmann, F., \& Kendall, J. (2005). The third sector and the policy process in Germany (Third sector European Policy Working Paper 9).

Zoch, G. (2018). Expanding public childcare services for under-threes: An empirical investigation of maternal employment and gender ideologies in East and West Germany. Ph.D. thesis, University of Bamberg, Bamberg.

Zoch, G., \& Hondralis, I. (2017). The expansion of low-cost, state-subsidized childcare availability and mothers' return-to-work behaviour in East and West Germany. European Sociological Review, 33(5), 693-707.

Zoch, G., \& Schober, P. S. (2018). Expansion of public childcare services and changing gender ideologies of parents in Germany. Journal of Marriage and Family, 80(4), 1020-1039.

Open Access This chapter is licensed under the terms of the Creative Commons Attribution 4.0 International License (http://creativecommons.org/licenses/by/4.0/), which permits use, sharing, adaptation, distribution and reproduction in any medium or format, as long as you give appropriate credit to the original author(s) and the source, provide a link to the Creative Commons licence and indicate if changes were made.

The images or other third party material in this chapter are included in the chapter's Creative Commons licence, unless indicated otherwise in a credit line to the material. If material is not included in the chapter's Creative Commons licence and your intended use is not permitted by statutory regulation or exceeds the permitted use, you will need to obtain permission directly from the copyright holder.

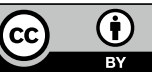

